\title{
Características da carcaça e viabilidade econômica do uso de cloridrato de ractopamina para suínos em terminação com alimentação à vontade ou restrita
}

\author{
Carcass characteristics and economic viability of the use of ractopamine for finishing swine with ad \\ libitum or restricted feeding
}

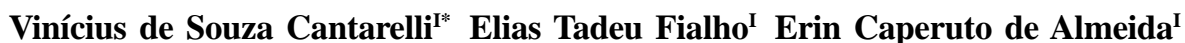 \\ Márcio Gilberto Zangeronimo ${ }^{I}$ Níkolas de Oliveira Amaral ${ }^{\mathrm{I}}$ José Augusto de Freitas Lima $^{\mathrm{I}}$
}

RESUMO

$O$ objetivo neste trabalho foi avaliar a suplementação de 5ppm de ractopamina (RAC) na ração, associada ou não à restrição alimentar, sobre as características da carcaça de suínos em terminação e a viabilidade econômica do seu uso. Foram utilizados 30 suínos machos castrados, Agroceres-PIC (peso vivo de 107,2 $\pm 6,2 \mathrm{~kg}$ ), recebendo as dietas experimentais durante os 28 dias que antecederam o abate. Foi utilizado um delineamento em blocos casualizados em esquema fatorial $2 \times 2+1$ (com ou sem RAC em rações com $1,04 \%$ de lisina total; à vontade ou restrição alimentar de 15\%; e um tratamento adicional - controle - fornecido à vontade, sem RAC, contendo $0,8 \%$ de lisina total - ração padrão), totalizando cinco tratamentos e seis repetições. A adição da RAC por si só aumentou a área de olho de lombo, a porcentagem de carne e a relação carne:gordura na carcaça, o índice de bonificação, a receita bruta e a receita líquida da produção e reduziu a espessura de toucinho dos animais. Quando associada à restrição alimentar, a RAC diminuiu a porcentagem de gordura na carcaça. Comparado à ração controle, a RAC aumentou o rendimento da carcaça, a porcentagem de carne na carcaça e a receita bruta paga ao produtor e reduziu a espessura de toucinho. Quando associada à restrição alimentar, diminuiu a porcentagem de gordura $e$ aumentou a relação carne:gordura na carcaça e o índice de bonificação. Assim, a suplementação com 5ppm de RAC, associada ou não à restrição alimentar, melhora as características da carcaça e viabiliza economicamente a produção.

Palavras-chave: B-agonista, modificador de carcaça, repartidor de nutriente, restrição alimentar, tipificação da carcaça.

\section{ABSTRACT}

The objective of this research was to evaluate the supplementation of 5ppm of ractopamine (RAC), associated or not with feed restriction, on carcass characteristics on finishing pigs and the economic viability of its use. Thirty hybrid barrows (life weight of $107.2 \pm 6.2 \mathrm{~kg}$ ), receiving the experimental diets during 28 days before the slaughter. A randomized blocks design in factorial scheme $2 \times 2+1$ (with or without RAC in diets with $1.04 \%$ of total lysine; ad libitum or feed restriction of $15 \%$ and an additional treatment - control - ad libitum, without $R A C$ containing $0.8 \%$ of lysine - standard diet), totalizing five treatments and six replicates. The addiction of RAC per se increased the loin eye area, the meat percentage, the carcass meat:fat ratio, the allowance index, the gross earnings and the production net earnings and decreased the animals backfat thickness. When associated with feed restriction, the RAC decreased the carcass fat percentage. Compared to standard diet, the RAC increased the carcass yield, the carcass meat percentage and the allowance index paid to the producer and decreased the backfat thickness. The RAC associated at the feed restriction decreased the fat carcass percentage and increased the carcass meat:fat ratio and the gross earnings. Thus, the supplementation with 5ppm of RAC, associated or no at the feed restriction, improves the carcass characteristics and the economic viability of production.

Key words: $\beta$-agonist, carcass modifier, splitter nutrient, feed restriction, carcass typing.

\section{INTRODUÇÃO}

A atividade suinícola está, constantemente, buscando métodos econômicos para aumentar a

IDepartamento de Zootecnia, Universidade Federal de Lavras (UFLA), CP 3037, 37200-000, Lavras, MG, Brasil. E-mail: viniciuscantarelli@yahoo.com.br. *Autor para correspondência. 
eficiência de produção e, ao mesmo tempo, a qualidade da carcaça, de modo a manter a sustentabilidade da atividade e atender às exigências do consumidor. $\mathrm{Na}$ nutrição, a restrição alimentar e a utilização de ractopamina podem ser alternativas interessantes, pois interferem na composição das carcaças e melhoram a eficiência de produção.

A restrição no consumo tem sido associada á melhora na eficiência alimentar e redução na deposição de gordura na carcaça (WARPECHOWSKI et al., 1999; BERTOL et al., 2001), favorecendo animais com carcaça mais magra e com maior percentual de carne em relação aos alimentados à vontade, principalmente, na fase de terminação (PEREIRA et al., 1987; LEYMASTER \& MERSMANN, 1991). A ractopamina também tem sido associada a efeitos benéficos por reduzir a quantidade de gordura (MIMBS et al., 2005) e aumentar a quantidade de carne na carcaça de suínos (STOLLER et al., 2003). Tais resultados podem significar melhores preços na indústria.

Nesse contexto, a tipificação de carcaça é cada vez mais evidente, dentro dos sistemas de produção, em especial, em regiões onde a suinocultura é intensa. Segundo GUIDONI (2000), a suinocultura industrial melhora continuamente a qualidade de seus produtos não só através da genética, mas também por meio de estratégias nutricionais que resultam em carcaça com maior quantidade de carne, menor espessura de toucinho e maior área de olho de lombo. Tais características são interessantes para a indústria, uma vez que há maior possibilidade de agregar valores ao produto final e, ao mesmo tempo, atender às exigências do mercado consumidor por um produto de melhor qualidade.

Atualmente, a tipificação de carcaças de suínos, praticada por alguns frigoríficos de médio e grande porte, é usada, principalmente, para a compra do suíno vivo. É um parâmetro utilizado para bonificar a carcaça paga ao produtor e tem sido usado como estratégia comercial para incentivar a produção de carcaças com mais carne e menos gordura. Qualquer estratégia visando à melhoria da qualidade da carcaça pode ser um efeito positivo para aumento da lucratividade do setor.

Além da redução do custo com rações, a restrição alimentar é associada à melhoria da qualidade da carcaça (STOLLER et al., 2003; MIMBS et al., 2005). No entanto, poucos trabalhos estudaram a combinação entre diferentes formas de arraçoamento e o uso da ractopamina. No trabalho de SMITH et al. (1995), foram observados efeitos positivos dessa associação que pode potencializar as melhorias na qualidade das carcaças com o uso da ractopamina, aumentando ainda mais a valorização na comercialização do produto final com o uso dessa substância.

Dessa forma, o objetivo neste trabalho foi avaliar as características e composição de carcaça e aspectos econômicos da adição de ractopamina na ração de suínos em terminação, associados ou não à restrição alimentar.

\section{MATERIAL E MÉTODOS}

O experimento foi conduzido no Setor de Suinocultura do Departamento de Zootecnia da Universidade Federal de Lavras, em Lavras, Região Sul do Estado de Minas Gerais. De um total de 60 suínos machos castrados Agroceres-PIC (peso inicial

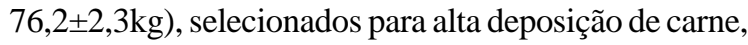
procedentes de uma granja comercial, 30 foram utilizados para avaliação das carcaças. Foram alojados dois animais em baia com piso, parcialmente, ripado e com área de 2,30 x 1,5m.

As dietas experimentais foram oferecidas durante um período de 28 dias, antes do abate. Os tratamentos foram assim estabelecidos: T1) dieta com ractopamina e $1,04 \%$ de lisina total, fornecida à vontade; T2) dieta com ractopamina e 1,04\% de lisina total, fornecida com $15 \%$ de restrição da ração em relação à T1; T3) dieta sem ractopamina e 1,04\% de lisina total, fornecida à vontade; T4) dieta sem ractopamina e 1,04\% de lisina total, fornecida com 15\% de restrição da ração em relação à T3; T5) tratamento controle, sem ractopamina, com $0,8 \%$ de lisina total e fornecida à vontade, formulado esse de acordo com as recomendações para suínos machos castrados, de alto potencial genético. O tratamento controle foi elaborado para fins de comparação com rações-padrão, fornecidas à vontade. Foi utilizado um delineamento experimental em blocos casualizados (peso inicial dos animais), em esquema fatorial 2 × $2+1$ (dois níveis de RAC; duas formas de arraçoamento e um tratamento adicional), totalizando cinco tratamentos e seis repetições. Os tratamentos do esquema fatorial tiveram o nível de lisina ajustado de acordo com MITCHELL et al. (1991), os quais recomendam aumento desse aminoácido em 30\%. A parcela experimental para a análise consistiu de um animal, que foi abatido ao final do experimento. As dietas experimentais (Tabela 1) foram formuladas à base de milho e farelo de soja, suplementadas com vitaminas, minerais e aminoácidos, de forma a atender às exigências mínimas sugeridas por ROSTAGNO et al. (2005), exceto para a lisina dos tratamentos do esquema fatorial.

Durante o período experimental, o fornecimento de ração seguiu o protocolo de 
Tabela 1 - Composição centesimal e calculada das dietas experimentais.

\begin{tabular}{|c|c|c|c|c|}
\hline \multirow[b]{2}{*}{ Ingrediente (\%) } & \multicolumn{4}{|c|}{ - } \\
\hline & $\begin{array}{l}\text { Com ractopamina e } \\
1,04 \% \text { de lisina total }\end{array}$ & $\begin{array}{l}\text { Sem ractopamina e } \\
1,04 \% \text { de lisina total }\end{array}$ & $\begin{array}{c}\text { Sem ractopamina e } \\
0,80 \% \text { de lisina total }\end{array}$ & $\begin{array}{c}\text { Custo }\left(\mathrm{R} \$ \mathrm{~kg}^{-1}\right) \\
10 / 02 / 2007\end{array}$ \\
\hline Milho & 77,60 & 77,62 & 78,02 & 0,41 \\
\hline Farelo de soja & 19,5 & 19,5 & 19,5 & 0,48 \\
\hline Óleo de soja & 0,65 & 0,65 & 0,50 & 1,44 \\
\hline L-Lisine- $\mathrm{HCl}$ & 0,315 & 0,315 & 0,073 & 5,05 \\
\hline Fosfato Bicálcico & 0,8 & 0,8 & 0,8 & 0,85 \\
\hline Calcáreo & 0,57 & 0,57 & 0,57 & 0,06 \\
\hline Sal comum & 0,3 & 0,3 & 0,3 & 0,21 \\
\hline Premix Mineral $^{1}$ & 0,1 & 0,1 & 0,1 & 3,15 \\
\hline Premix vitamínico ${ }^{2}$ & 0,1 & 0,1 & 0,1 & 7,00 \\
\hline Tylan $250^{3}$ & 0,04 & 0,04 & 0,04 & 70,00 \\
\hline Paylean ${ }^{4}$ & 0,025 & 0,00 & 0,00 & 103,20 \\
\hline TOTAL & 100,0 & 100,0 & 100,0 & - \\
\hline Proteína bruta (\%) & 15,45 & $\begin{array}{c}\text { sição calculada----'- } \\
15,45\end{array}$ & 15,48 & -- \\
\hline Energia metabolizável $\left(\mathrm{kcal} \mathrm{kg}^{-1}\right)$ & 3260 & 3260 & 3260 & \\
\hline Lisina total (\%) & 1,04 & 1,04 & 0,80 & \\
\hline Lisina digestível (\%) & 0,86 & 0,86 & 0,69 & \\
\hline Metionina digestível (\%) & 0,231 & 0,231 & 0,232 & \\
\hline Treonina digestível (\%) & 0,504 & 0,504 & 0,505 & \\
\hline Triptofano digestível (\%) & 0,154 & 0,154 & 0,154 & \\
\hline Fósforo disponível (\%) & 0,245 & 0,245 & 0,245 & \\
\hline Cálcio (\%) & 0,485 & 0,485 & 0,485 & \\
\hline Ractopamina (ppm) & 5,00 & 0,00 & 0,00 & \\
\hline
\end{tabular}

${ }^{1}$ Composição por kg de produto: cálcio, 98,800mg; cobalto, 185mg; cobre, 15,750mg; ferro, 26,250mg; iodo, 1,470mg; manganês, 41,850mg; zinco, 77,999mg. ${ }^{2}$ Composição por kg de produto: ácido fólico, 116,55mg; ácido pantotênico, 2.333,5mg; biotina, 5,28mg; niacina, 5.600mg; piridoxina, 175mg; riboflavina, 933,3mg; tiamina, 175mg; Vit. A, 1.225 .000 U.I.; Vit. D Vit. $\mathrm{K}_{3}$, 700mg; Vit. $\mathrm{B}_{12}$, 6.825mg; selênio, $105 \mathrm{mg}$; antioxidante: $1.500 \mathrm{mg} .{ }^{3}$ Antibiótico a base de tilosina granulada. ${ }^{4}$ Cloridrato de ractopamina.

arraçoamento de acordo com o tratamento estipulado e a água foi fornecida à vontade. As dietas foram fornecidas à vontade apenas para os tratamentos T1 e T3 cujo consumo pelos animais, calculado diariamente, foi utilizado como parâmetro para verificar o consumo dos animais no dia seguinte que receberiam os tratamentos T2 e T4. A ração fornecida e os desperdícios foram pesados para a determinação do consumo de cada baia.

No dia que antecedeu o abate, um animal de cada baia foi selecionado (aqueles que apresentavam peso mais próximo da média - 106,6 ×6,6kg) e mantido em jejum sólido por 12 horas e hídrico por 6 horas. Antes do abate, os animais foram pesados e abatidos por dessensibilização elétrica, com peso de $107,2 \pm 6,2 \mathrm{~kg}$, seguida de degola. Logo após, a evisceração, as carcaças foram serradas longitudinalmente ao meio e pesadas. A meia carcaça esquerda de cada suíno foi resfriada a uma temperatura média de $4^{\circ} \mathrm{C}$ durante 24 horas, para sua posterior avaliação e dissecação, separando os tecidos cárneos, a gordura e os ossos. Todas as mensurações foram feitas de acordo com o Método Brasileiro de Avaliação de Carcaça (ABCS, 1973).

Após a obtenção das variáveis de carcaça, realizou-se a avaliação econômica dos tratamentos. $\mathrm{O}$ valor em reais recebido pelos suínos, representado pela receita bruta (RB), foi determinado com base no índice de bonificação (IB), segundo descrito por GUIDONI (2000), e no peso da carcaça quente (PCARC), conforme FÁVERO et al. (1997):

$\mathrm{RB}(\mathrm{R} \$)=(\mathrm{IB} *$ [preço do quilograma do suíno vivo $(\mathrm{R} \$) /$ 0,7145])*PCARC $(\mathrm{kg})$

Com base nos preços dos ingredientes das dietas praticados em Lavras, em fevereiro de 2007, foi determinado o custo com alimentação $\left(\mathrm{C}_{\text {alimentação }}\right)$ de cada suíno, pelo do consumo total de ração de cada 
animal, durante o período experimental, e do custo das dietas experimentais, conforme fórmula:

$\mathrm{C}_{\text {alimentação }}(\mathrm{R} \$)=$ consumo total de ração $(\mathrm{kg}) *$ custo da dieta $(\mathrm{R} \$)$

O custo do peso inicial do suíno $\left(\mathrm{C}_{\text {suíno }}\right)$ foi calculado para isolar a variável peso inicial. Levou-se em conta o preço do suíno no início do período experimental, de acordo com o preço do quilograma praticado pela Bolsa de Suíno de Minas Gerais no mês de Fevereiro de 2007 cujo cálculo foi realizado pela fórmula:

$\mathrm{C}_{\text {suíno }}(\mathrm{R} \$)$ = peso do animal $(\mathrm{kg}) *$ preço do quilograma do suíno vivo ( $\mathrm{R} \$$ )

O custo total $\left(\mathrm{C}_{\text {total }}\right)$ foi calculado pela soma do custo com a alimentação $\left(\mathrm{C}_{\text {alimentação }}\right)$ mais o custo do peso inicial do suíno $\left(\mathrm{C}_{\text {súno }}\right)$, de acordo com a fórmula descrita a seguir:

$\mathrm{C}_{\text {total }}(\mathrm{R} \$)=\mathrm{C}_{\text {alimentação }}(\mathrm{R} \$)+\mathrm{C}_{\text {súno }}(\mathrm{R} \$)$

Por fim, a receita líquida (RL) foi calculada, subtraindo-se o custo total $\left(\mathrm{C}_{\text {total }}\right)$ da $\mathrm{RB}$ :

$\mathrm{RL}(\mathrm{R} \$)=\mathrm{RB}(\mathrm{R} \$)-\mathrm{C}_{\text {total }}(\mathrm{R} \$)$

As variáveis analisadas foram rendimento de carcaça, área de olho de lombo, espessura de toucinho, percentagem de carne, percentagem de gordura, relação carne:gordura, índice de bonificação da carcaça, receita bruta, custo total e receita líquida.
As análises estatísticas foram realizadas, utilizando-se o PROC GLM do pacote estatístico SAS (2001). Efetuou-se uma análise de variância global com todos os tratamentos, a fim de se obter o quadrado médio do resíduo, que foi utilizado para testar as fontes de variação e o fatorial. O teste Dunnet, a 5\%, foi utilizado para comparar o tratamento controle com os demais tratamentos e o teste $\mathrm{F}$ para comparar os tratamentos no esquema fatorial.

\section{RESULTADOS E DISCUSSÃO}

Na tabela 2, apresentam-se os valores de consumo de ração médio diário, consumo de lisina total médio diário e consumo de energia metabolizável médio diário cujos valores seguiram o propósito deste trabalho. Na tabela 3, estão apresentados os resultados de peso da carcaça quente, rendimento de carcaça, área de olho de lombo e espessura de toucinho. Não houve efeito da interação $(\mathrm{P}>0,05)$ entre a suplementação de RAC e a forma de arraçoamento sobre essas variáveis. Comparado ao tratamento-testemunha, a RAC e a forma de arraçoamento não afetaram $(\mathrm{P}>0,05)$ o peso da carcaça quente. A RAC não afetou $(\mathrm{P}>0,05)$ o peso da carcaça, enquanto que o arraçoamento à vontade melhorou $(\mathrm{P}<0,05)$ esta variável em relação às rações

Tabela 2 - Consumo diário de ração, de energia e de lisina de suínos em terminação suplementados ou não com 5ppm de ractopamina (RAC), com ou sem restrição alimentar durante 28 dias de experimento $(n=6)^{1}$.

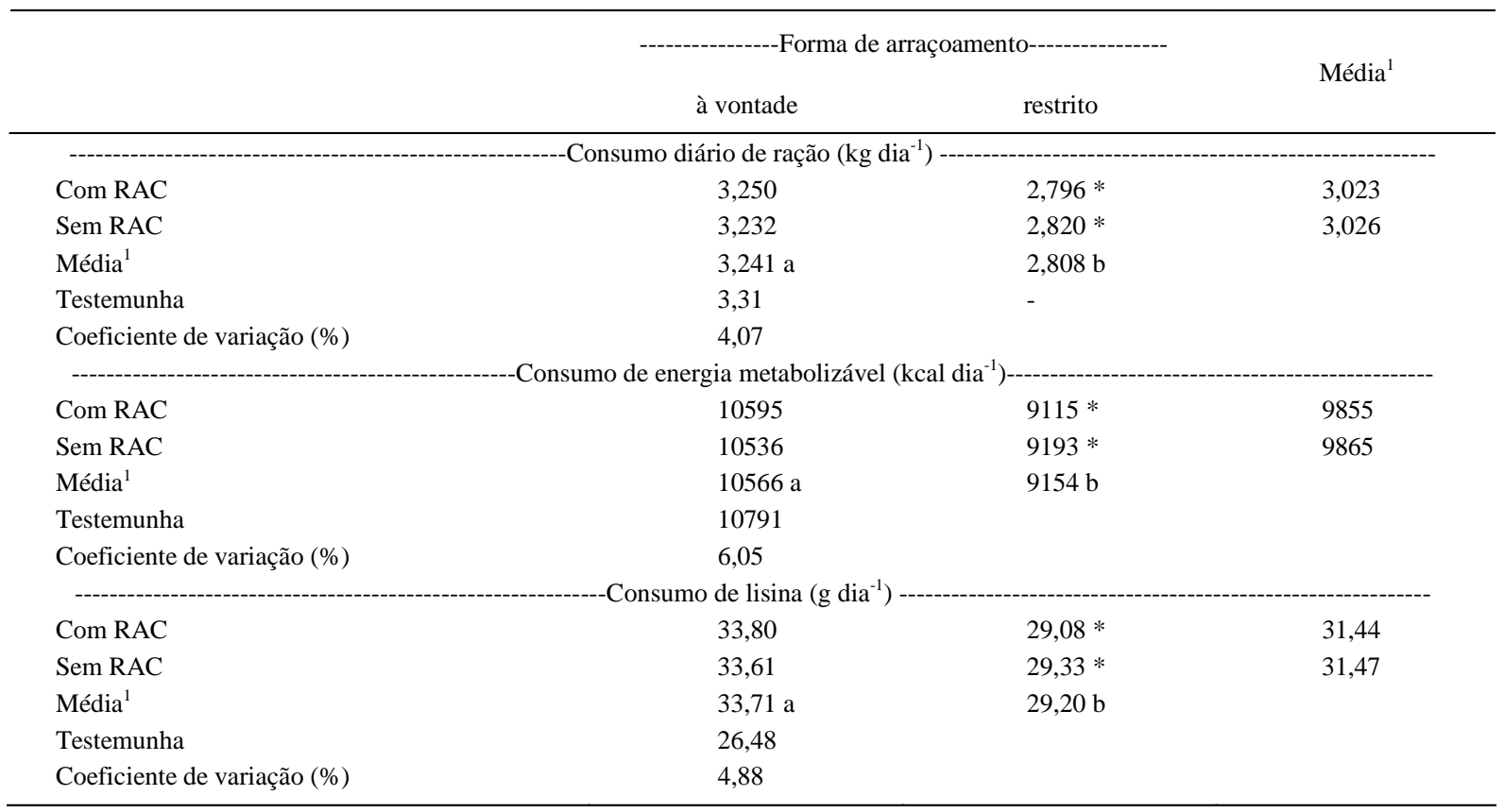

Testemunha - ração sem ractopamina, fornecida ad libitum e com $0,8 \%$ de lisina total na dieta.

${ }^{1}$ Médias seguidas de diferentes letras minúsculas na linha e maiúsculas na coluna diferem pelo teste $\mathrm{F}(\mathrm{P}<0,05)$.

* Diferem do tratamento testemunha pelo teste Dunnet $(\mathrm{P}<0,05)$.

Ciência Rural, v.39, n.3, mai-jun, 2009. 
Tabela 3 - Rendimento de carcaça, área de olho de lombo e espessura de toucinho da carcaça de suínos em terminação suplementados ou não com 5ppm de ractopamina (RAC), com ou sem restrição alimentar durante 28 dias de experimento $(n=6)^{1}$.

\begin{tabular}{|c|c|c|c|}
\hline & \multicolumn{2}{|c|}{ Forma de arraçoamento } & \multirow{2}{*}{ Média $^{1}$} \\
\hline & à vontade & restrito & \\
\hline \multicolumn{4}{|c|}{-------------------------Peso da carcaça quente------------------------ } \\
\hline Com ractopamina & 79,22 & 77,12 & 78,18 \\
\hline Sem ractopamina & 78,70 & 76,66 & 77,68 \\
\hline Média $^{1}$ & 78,96 a & $76,90 \mathrm{~b}$ & \\
\hline Testemunha & 77,86 & & \\
\hline Coeficiente de Variação (\%) & 2,56 & & \\
\hline \multicolumn{4}{|c|}{---------------------Rendimento de carcaça (\%)--------------------- } \\
\hline Com ractopamina & $81,43 *$ & $81,41 *$ & 81,40 \\
\hline Sem ractopamina & $81,63 *$ & $81,38 *$ & 81,50 \\
\hline Média $^{1}$ & 81,53 & 81,40 & \\
\hline Testemunha & 79,70 & & \\
\hline Coeficiente de Variação (\%) & 1,79 & & \\
\hline \multicolumn{4}{|c|}{ - } \\
\hline Com ractopamina & 45,96 & 46,23 & $46,09 \mathrm{~A}$ \\
\hline Sem ractopamina & 41,40 & 43,40 & $42,40 \mathrm{~B}$ \\
\hline Média $^{1}$ & 43,68 & 44,81 & \\
\hline Testemunha & 44,34 & & \\
\hline Coeficiente de Variação (\%) & 5,66 & & \\
\hline \multicolumn{4}{|c|}{--------------------Espessura de toucinho (mm) -------------------- } \\
\hline Com ractopamina & $14,00 *$ & $14,78 *$ & $14,41 \mathrm{~B}$ \\
\hline Sem ractopamina & 17,49 & $15,03 *$ & $16,26 \mathrm{~A}$ \\
\hline Média $^{1}$ & 15,87 & 14,80 & \\
\hline Testemunha & 18,09 & & \\
\hline Coeficiente de Variação (\%) & 11,55 & & \\
\hline
\end{tabular}

Testemunha - ração sem ractopamina, fornecida ad libitum e com $0,8 \%$ de lisina total na dieta.

1 Médias seguidas de diferentes letras minúsculas na linha e maiúsculas na coluna diferem pelo teste $\mathrm{F}(\mathrm{P}<0,05)$.

* Diferem do tratamento testemunha pelo teste Dunnet $(\mathrm{P}<0,05)$.

com elevado teor de lisina, independentemente da presença deste aditivo. $\mathrm{O}$ aumento da ingestão diária de nutrientes, de certa forma, contribuiu para a obtenção desses resultados.

Quanto ao rendimento de carcaça, a RAC melhorou $(\mathrm{P}<0,05)$ seus valores apenas quando comparada ao tratamento-testemunha. Resultado semelhante foi encontrado em outros trabalhos (CARR et al., 2005; WEBER et al., 2006) para essa variável. Por outro lado, BUDIÑO et al. (2005) não encontraram efeito da RAC no rendimento de carcaça. De acordo com revisão feita por MILLS (2002), a ractopamina aumenta a percentagem de carne devido ao efeito sobre o crescimento do músculo esquelético e não em outros órgãos. Segundo STAHLY (1990), os ß-agonistas aumentam a proporção de nutrientes depositados na carcaça em relação à deposição nas vísceras. Da mesma forma, o aumento dos níveis de lisina, associados ou não à restrição alimentar, melhorou o rendimento de carcaça $(\mathrm{P}<0,05)$ em relação ao tratamento-testemunha. Nesse caso, a lisina pode ter favorecido a síntese protéica e, conseqüentemente, a maior deposição de carne na carcaça dos animais. Considerando os resultados do fatorial, a forma de arraçoamento não influenciou $(\mathrm{P}>0,05)$ o rendimento da carcaça em rações com níveis elevados de lisina. De acordo com BERTOL et al. (2001), a restrição alimentar por si só não influencia esta variável. Por outro lado, WARPECHOWSKI et al. (1999) observaram menor rendimento de carcaça para animais em restrição alimentar. De acordo com esses autores, o menor depósito de gordura visceral decorrente do menor aporte de nutrientes da dieta pode afetar o peso das vísceras. A variação encontrada nesses trabalhos pode estar relacionada ao nível de restrição imposta, o que está relacionado, diretamente, ao consumo de lisina e energia, principalmente, e também à genética utilizada, além da fase do ciclo produtivo dos animais. No presente trabalho, a restrição de 15\% aos animais no final da fase de terminação não resultou em melhorias no rendimento da carcaça.

Quanto à área de olho de lombo, a adição de RAC ou o aumento do nível de lisina, nas rações associadas a diferentes formas de arraçoamento, não afetaram $(\mathrm{P}>0,05)$ seus valores em relação ao tratamento-testemunha. Considerando as médias do fatorial, a RAC aumentou $(\mathrm{P}<0,01)$ a área de olho de lombo, quando comparada a dietas sem o uso desse composto. Esses resultados contradizem os encontrados por MIMBS et al. (2005) e por PÉREZ et al. (2006). No entanto, na maioria dos trabalhos que avaliaram a suplementação da RAC para suínos, foram observadas melhoras nessa variável (CARR et al., 2005; XIONG et al., 2006. WEBER et al., 2006). Segundo esses autores, a RAC influencia o aumento da síntese de proteína muscular, o que pode ter acontecido nos resultados observados para essa variável.

A forma de arraçoamento não influenciou ( $\mathrm{P}>0,05)$ a área de olho de lombo. Resultado semelhante foi encontrado por WARPECHOWSKI et al. (1999). Da mesma forma o observado para o rendimento de carcaça, o nível de restrição imposto não foi suficiente para prejudicar a síntese protéica dos animais.

Houve redução $(\mathrm{P}<0,05)$ na espessura de toucinho, quando a ractopamina foi utilizada, sendo observado decréscimo de 20,34\% e 11,38\% em relação 
ao tratamento-controle e tratamentos sem RAC com elevado teor de lisina. Resultados semelhantes foram encontrados por PÉREZ et al. (2006) e MIMBS et al. (2005). Observou-se ainda que a restrição alimentar e aumento dos níveis de lisina reduziram a gordura subcutânea em 16,92\%, quando comparados aos animais do tratamento-controle. Resultado semelhante foi encontrado por WARPECHOWSKI et al. (1999). Porém, BERTOL et al. (2001) não encontraram efeito da restrição alimentar sobre essa variável.

Na tabela 4, estão apresentados o resultados obtidos para porcentagem de carne, porcentagem de gordura, relação carne:gordura, índice de bonificação da carcaça, receita bruta, custo total e receita liquida. Não houve efeito da interação $(\mathrm{P}>0,05)$ entre RAC e formas de arraçoamento para porcentagem de carne, relação carne:gordura, índice de bonificação da carcaça, receita bruta, custo total e receita liquida.

A porcentagem de carne na carcaça foi maior $(\mathrm{P}<0,05)$ em relação ao tratamento-controle para os animais que receberam a RAC, independentemente da forma de arraçoamento (à vontade ou restrita). Esses valores corresponderam a um aumento de 3,37\% com RAC à vontade e 6,25\% com RAC e arraçoamento restrito. Nos estudos de HERR et al. (2000), a porcentagem de carne, na carcaça dissecada, foi maior para os animais suplementados com RAC, com melhoras semelhantes, quando comparada ao tratamento controle, sem adição de RAC.

Com relação à porcentagem de gordura, o uso de RAC associado à restrição alimentar diminuiu $(\mathrm{P}<0,05)$ seus valores em torno de 17,3\%. Considerando os tratamentos do fatorial, houve efeito $(\mathrm{P}<0,05)$ da interação entre a suplementação com RAC e a forma de arraçoamento. A suplementação com RAC associada à restrição alimentar reduziu $(\mathrm{P}<0,05)$ esse valor em 15,0 e 14,1, quando comparada aos tratamentos com RAC e ração à vontade; e sem RAC e ração restrita, respectivamente. Isto pode estar relacionado ao efeito da RAC em direcionar os nutrientes para a síntese de tecido muscular e ao menor aporte energético propiciado pela restrição para o armazenamento na forma de gordura. Esses resultados mostraram-se bastante interessantes, pois representam informações importantes para tomada de decisão, quando se buscam carcaças mais magras, principalmente, para as empresas integradoras que detêm o sistema produtivo e industrial e que visam a produzir animais com qualidade de matéria-prima para o atendimento das exigências do consumidor por produtos processados ou semi-elaborados com menor teor de gordura.
Com relação ao índice de bonificação, apenas o tratamento com RAC e restrição alimentar apresentou maiores valores em relação ao tratamentotestemunha, correspondendo a uma melhora de 5,81\%. Considerando as médias do fatorial, houve diferenças $(\mathrm{P}<0,01)$ entre suínos que receberam $\mathrm{RAC}$ na ração com relação àqueles que não receberam, apresentando índices 3,9 maiores para as carcaças de suínos suplementados com esse microingrediente de ração. Esse resultado confirma os anteriores obtidos com a RAC no que diz respeito à qualidade das carcaças.

Para os resultados de viabilidade econômica, observou-se maior receita bruta $(\mathrm{P}<0,05)$ com o grupo de animais que receberam RAC, quando comparados ao tratamento controle, independentemente da forma de arraçoamento. Essa melhora foi de $\mathrm{R} \$ 18,62$, representando um aumento de 7,39\%. Com relação aos demais tratamentos, a suplementação com RAC, nas rações à vontade ou restritas, melhoraram $(\mathrm{P}<0,01)$ a receita em $\mathrm{R} \$ 12,59$, ou seja, em 4,88\% em relação às dietas sem suplementação.

Com relação ao custo total de produção de suíno, em relação ao tratamento-controle, apenas o tratamento com RAC associado ao arraçoamento ad libitum apresentou um maior custo, correspondendo a um aumento de R\$ 6,00 ou 2,98\%. Além disso, considerando as médias do fatorial, o custo total foi maior $(\mathrm{P}<0,05)$ para os tratamentos com RAC em R\$ 2,83 , enquanto que o arraçoamento à vontade representou um aumento $(\mathrm{P}<0,05)$ no custo de $\mathrm{R} \$ 4,66$ ou 2,32\% em relação ao arraçoamento restrito. Entretanto, a receita líquida observada, com ou sem o uso da RAC, em rações com elevado teor de lisina fornecida à vontade ou restrita, não diferiu $(\mathrm{P}>0,05)$ do tratamento-controle, apesar de a receita ser maior em $\mathrm{R} \$ 15,82$ ou 31,18\% para os tratamentos com RAC, independentemente da forma de arraçoamento. Quando se suplementaram os animais com RAC, em rações com elevado teor desse aminoácido, observou-se um aumento $(\mathrm{P}<0,05)$ na receita de $\mathrm{R} \$ 9,76$, representando uma melhora de $17,18 \%$.

\section{CONCLUSÕES}

A suplementação com 5ppm de RAC, associada ou não à restrição alimentar, melhora as características da carcaça e viabiliza, economicamente, a produção. A restrição alimentar aumenta a porcentagem de carne, entretanto não influencia a receita líquida final obtida pelo produtor. 
Tabela 4 - Porcentagem de carne, porcentagem de gordura, relação carne:gordura, índice de bonificação, receita bruta, custo total e receita líquida da carcaça de suínos em terminação alimentados com rações suplementadas ou não com 5ppm de ractopamina (RAC), com ou sem restrição alimentar durante 28 dias $(n=6)^{1}$.

\begin{tabular}{|c|c|c|c|}
\hline & \multicolumn{2}{|c|}{-----------Forma de arraçoamento-----------. } & \multirow{2}{*}{ Média $^{1}$} \\
\hline & à vontade & restrito & \\
\hline \multicolumn{4}{|c|}{ 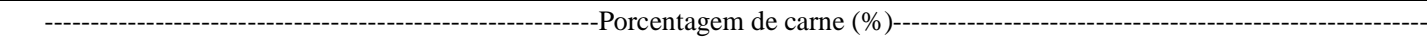 } \\
\hline Com ractopamina & $56,08 *$ & $57,93 *$ & $57,00 \mathrm{~A}$ \\
\hline Sem ractopamina & 52,66 & 54,61 & $53,64 \mathrm{~B}$ \\
\hline Média ${ }^{1}$ & $54,37 \mathrm{~b}$ & $56,27 \mathrm{a}$ & \\
\hline Testemunha & 52,55 & & \\
\hline Coeficiente de variação (\%) & 3,66 & & \\
\hline Com ractopamina & $30,06 \mathrm{~b}$ & $25,55 \mathrm{~A} \mathrm{a} *$ & 27,80 \\
\hline Sem ractopamina & 30,41 & 29,76 B & 30,08 \\
\hline Média $^{1}$ & 30,23 & 27,65 & \\
\hline Testemunha & 30,90 & & \\
\hline Coeficiente de variação (\%) & 6,73 & & \\
\hline \multicolumn{4}{|c|}{ - } \\
\hline Com ractopamina & 1,76 & 2,38 & $2,07 \mathrm{~B}$ \\
\hline Sem ractopamina & 1,68 & 1,83 & $1,76 \mathrm{~A}$ \\
\hline Média $^{1}$ & 1,72 & 2,11 & \\
\hline Testemunha & 1,65 & & \\
\hline Coeficiente de variação (\%) & 9,94 & & \\
\hline Com ractopamina & 105,5 & $107,4 *$ & $106,5 \mathrm{~A}$ \\
\hline Sem ractopamina & 101,8 & 103,3 & $102,5 \mathrm{~B}$ \\
\hline Média $^{1}$ & 103,7 & 105,3 & \\
\hline Testemunha & 101,5 & & \\
\hline Coeficiente de variação (\%) & 2,06 & & \\
\hline \multicolumn{4}{|c|}{--10 } \\
\hline Com ractopamina & $271,73 *$ & $269,23 *$ & $270,48 \mathrm{~A}$ \\
\hline Sem ractopamina & 259,33 & 256,45 & $257,89 \mathrm{~B}$ \\
\hline Média $^{1}$ & 265,53 & 262,84 & \\
\hline Testemunha & 251,86 & & \\
\hline Coeficiente de variação (\%) & 2,67 & & \\
\hline \multicolumn{4}{|c|}{ - } \\
\hline Com ractopamina & $207,14 *$ & 200,69 & 203,91 A \\
\hline Sem ractopamina & 202,52 & 199,65 & $201,08 \mathrm{~B}$ \\
\hline Média $^{1}$ & 204,83 a & $200,17 \mathrm{~b}$ & \\
\hline Testemunha & 201,14 & & \\
\hline Coeficiente de variação (\%) & 1,64 & & \\
\hline --------------- & eceita Liquic & ----------- & ----------- \\
\hline Com ractopamina & 64,57 & 68,53 & $66,55 \mathrm{~A}$ \\
\hline Sem ractopamina & 56,82 & 56,77 & $56,79 \mathrm{~B}$ \\
\hline Média $^{1}$ & 60,69 & 62,65 & \\
\hline Testemunha & 50,73 & & \\
\hline Coeficiente de variação (\%) & 11,73 & & \\
\hline
\end{tabular}

Testemunha - ração sem ractopamina, fornecida ad libitum e com 0,8\% de lisina total na dieta.

${ }^{1}$ Médias seguidas de diferentes letras minúsculas na linha e maiúsculas na coluna diferem pelo teste $\mathrm{F}(\mathrm{P}<0,05)$.

* Diferem do tratamento testemunha pelo teste Dunnet $(\mathrm{P}<0,05)$. 


\section{REFERÊNCIAS}

ABCS - ASSOCIAÇÃO BRASILEIRA DE CRIADORES DE SUÍNOS. Método brasileiro de classificação de carcaças. Estrela: ABCS, 1973. 17p. (Publicação Técnica n.2).

BERTOL, T.M. et al. Efeito do peso do suíno em terminação ao início da restrição alimentar sobre o desempenho e a qualidade da carcaça. Revista Brasileira de Zootecnia, v.30, n.2, p.417-424, 2001.

BUDIÑO, F.E.L. et al. Desempenho e características de carcaça de suínos em terminação recebendo diferentes níveis e marcas comerciais de cloridrato de ractopamina. Boletim da Indústria Animal, v.62, n.3, p.245-250, 2005.

CARR, S.N. et al. The effects of ractopamine hydrochloride on lean carcass yields and pork quality characteristics. Journal of Animal Science, v.83, n.12, p.2886-2893, 2005.

FÁVERO, J.A. et al. Predição do índice de valorização de carcaças suínas em função do peso e do percentual de carne. In: CONGRESSO BRASILEIRO DE VETERINÁRIOS ESPECIALISTAS EM SUÍNO, 8., 1997, Foz do Iguaçu, PR. Anais... Concórdia: Embrapa - CNPSA, 1997. p.405-406.

GUIDONI, A.L. Melhoria de processos para a tipificação e valorização de carcaças suínas no Brasil. In: CONFERÊNCIA INTERNACIONAL VIRTUAL SOBRE QUALIDADE DE CARNE SUÍNA. EMBRAPA SUÍNOS E AVES, 2000, Concórdia, SC. Anais... Concórdia: EMBRPA, 2000. 14p.

HERR, C.T. et al. Effect of nutritional level while feeding Paylean $^{\mathrm{TM}}$ to late-finishing swine - swine day. Purde: Purdue University, 2000. p.89-95

LEYMASTER, K.A.; MERSMANN, H.J. Effect of limited feed intake on growth of subcutaneous adipose tissue layers and carcass composition in swine. Journal of Animal Science, v.64, p.2837-2843, 1991.

MIMBS, K.J. et al. Effects of ractopamine on performance and composition of pigs phenotypically sorted into fat and lean groups. Journal of Animal Science, v.83, p.13611369, 2005.

MILLS, S.E. et al. Stereoselectivity of porcine beta-adrenergic receptors for ractopamine stereoisomers. Journal of Animal Science, v.81, p.122-194, 2002.

MITCHELL, A.D. et al. Influence of level of dietary protein or energy on effects of ractopamine in finishing swine. Journal of Animal Science, v.69, p.4487-4495, 1991.
PEREIRA, J.A. et al. Efeitos da restrição alimentar sobre o desempenho de suínos em crescimento-terminação. Revista Brasileira de Zootecnia, v.16, p.111-119, 1987.

PÉREZ, A. et al. Efectos de la ractopamina y lisina sobre la deposición de grasa en cerdos seleccionados magros en la fase de engorde. Zootecnia Tropical, v.24, n.4, p.435-455, 2006.

ROSTAGNO, H.S. et al. Tabelas brasileiras para aves e suínos: composição de alimentos e exigências nutricionais. 2.ed. Viçosa: UFV, 2005. 186p.

SMITH, W.C. et al. Effects of ractopamine on the growth and carcass quality of entire male and female pigs fed ad libitum or at a restricted level. New Zealand Journal of Agricultural Research, v.38, p.373-380, 1995.

STATISTICAL ANALYSIS SYSTEM - SAS. System for Microsoft Windows. Release 8.2. Cary, 2001. CD ROM.

STAHLY, T.S. Impact of somatotropin and beta-adrenergic agonists on growth, carcass composition and nutrient requirements of pigs . In: HARESIGN, W.; COLE, D.J.A. (Ed.). Recent advances in animal nutrition. Boston: Buttenworths, 1990. p.197-205.

STOLLER, G.M. et al. The effect of feeding ractopamine (Paylean) on muscle quality and sensory characteristics in three diverse genetic lines of swine. Journal of Animal Science, v.81, p.1508-1516, 2003.

WARPECHOWSKI, M.B. et al. Efeito da restrição alimentar quantitativa sobre o desempenho e as características da carcaça de suínos em terminação. Archives of Veterinarian Science, v.4, n.1, p.73-75, 1999

WEBER, T.E. et al. Evaluation of the effects of dietary fat, conjugated linoleic acid, and ractopamine on growth performance, pork quality, and fatty acid profiles in genetically lean gilts. Journal of Animal Science, v.84, p.720-732, 2006.

XIONG Y.L. et al. Effect of dietary ractopamine on tenderness and postmortem protein degradation of pork muscle. Meat Science, v.73, p.600-604, 2006. Disponível em: http://www.sciencedirect.com/ science?_ob=ArticleURL\&_udi=B6T9G-4JRVDBM$3 \& \_u s e r=687358 \& \_r d o c=1 \& \_f m t=\& \_o r i g=s e a r c h \& \_s o r t=d \& v i e w=c \&$ _acct $=$ C $000037899 \&$ _version $=1 \&$ _url Version $=0$ \&_userid=687358\&md5=35aa8e67cc73273 642f32fdeab9f0b46. Doi: 10.1016/j.meatsci.2006.02.016. 